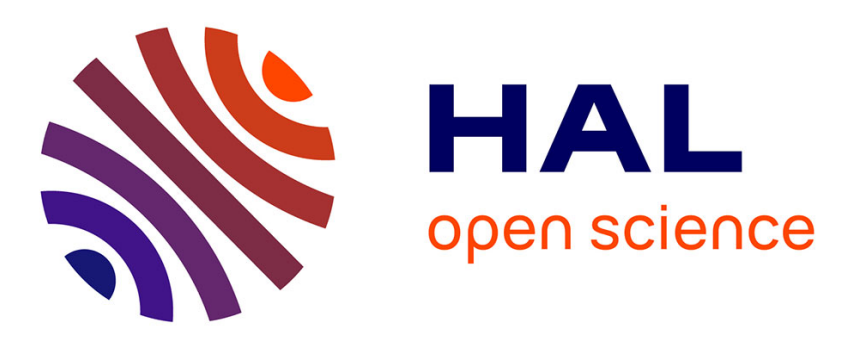

\title{
Electrochemical meso-functionalization of magnesium(II) porphine
}

Charles H. Devillers, Abdou K D Dimé, Hélène Cattey, Dominique Lucas

\section{To cite this version:}

Charles H. Devillers, Abdou K D Dimé, Hélène Cattey, Dominique Lucas. Electrochemical mesofunctionalization of magnesium(II) porphine. Chemical Communications, 2011, 47 (6), pp.1893-1895. $10.1039 / \mathrm{c} 0 \mathrm{cc} 04309 \mathrm{e}$. hal-03471794

\section{HAL Id: hal-03471794 \\ https://hal.science/hal-03471794}

Submitted on 9 Dec 2021

HAL is a multi-disciplinary open access archive for the deposit and dissemination of scientific research documents, whether they are published or not. The documents may come from teaching and research institutions in France or abroad, or from public or private research centers.
L'archive ouverte pluridisciplinaire HAL, est destinée au dépôt et à la diffusion de documents scientifiques de niveau recherche, publiés ou non, émanant des établissements d'enseignement et de recherche français ou étrangers, des laboratoires publics ou privés. 


\title{
Electrochemical meso-Functionalization of Magnesium(II) Porphine $\uparrow$
}

\author{
Charles H. Devillers, ${ }^{* a}$ Abdou K. D. Dimé, ${ }^{a}$ Hélène Cattey ${ }^{a}$ and Dominique Lucas ${ }^{* a}$ \\ Received (in $X X X, X X X)$ Xth $X X X X X X X X X 200 X$, Accepted Xth $X X X X X X X X X 200 X$ \\ First published on the web Xth $X X X X X X X X X 200 X$ \\ ${ }_{5}$ DOI: 10.1039/b000000x
}

\begin{abstract}
Regioselective meso-functionalization of the totally unsubstituted magnesium(II) porphine was performed by controlled potential electrolysis with pyridine and triphenylphosphine as nucleophiles leading to the original pyridinium and phosphonium substituted 10 derivatives, respectively. The crystallographic structure of the latter is described as the only meso-phosphonium porphyrin reported to date.
\end{abstract}

For many decades, porphyrins have been the subject of intense research in numerous areas such as artificial photosynthesis, 15 molecular electronic devices, electrochemical sensors and electrocatalysis. ${ }^{1}$ Porphine is the simplest representative of this family with peripheric ring free of any substituent. As such, great interest lies in this molecule as it could be used as a ready-to-build scaffold, with the prospect of progress in ${ }_{20}$ porphyrin synthesis. Despite such potential, very few studies have concerned the reactivity of porphine ${ }^{2}$ probably because of the poor commercial availability of this molecule, its difficult synthesis (low yield) and its very weak solubility in common organic solvents. Recently, an efficient and concise 25 synthesis was developed by the Lindsey research group leading in three steps to magnesium(II) porphine $1,{ }^{3}$ which is probably the most soluble among the other known metalloporphines. As its electrochemical properties had not yet been described in detail (only its first oxidation potential 30 was mentioned ${ }^{4}$ ), our first contributions in this field were dedicated to the electrochemical behaviour of $\mathbf{1}$ in $\mathrm{CH}_{2} \mathrm{Cl}_{2}{ }^{5}$ and in $\mathrm{CH}_{3} \mathrm{CN}{ }^{6}$ The low oxidation potential of $1\left(E_{p a}=0.70\right.$ V/SCE in $\left.\mathrm{CH}_{2} \mathrm{Cl}_{2} 0.1 \mathrm{M} \mathrm{TBAClO}_{4}\right)^{5}$ facilitates the access to the corresponding cation radical $\mathbf{1}^{++}$. As in the $\mathrm{OEP}^{7,8}$ and ${ }_{35} \mathrm{TPP}^{9,10}$ series, $\mathbf{1}^{++}$must be prone to react with a wide range of nucleophiles thus offering the opportunity to functionalize the macrocycle. Furthermore, the absence of substituent around the macrocycle makes it possible to test the respective reactivities of the meso and $\beta$ positions, as never done before 40 by electrochemical routes. Taking advantage of these unique features of magnesium porphine, our first results concerning its regioselective functionalization using pyridine and triphenylphosphine as nucleophiles are presented below.

After 1 had been synthesized according to Lindsey's 45 procedure, ${ }^{3}$ voltammetric studies were undertaken in pure pyridine. The cyclic voltammogram (CV) of 1 (Fig. 1A) reveals four totally irreversible anodic oxidations at $E_{\mathrm{pa}}=0.77$ (peak O1), $1.00(\mathrm{O} 2), \sim 1.2-1.3$ (shoulder, O3) and $1.49 \mathrm{~V}$ (O4) vs. SCE (all potential values in this communication will ${ }_{50}$ be given $v s$. SCE) and one reversible cathodic monoelectronic reduction at $E_{1 / 2}=-1.45 \mathrm{~V}\left(\Delta E_{p}=90 \mathrm{mV}, \mathrm{R} 3\right)$. Usually, metalloporphyrins with non-electroactive metal like $\mathrm{Mg}$ undergoes reversibly two ring-centered reductions and two ring-centered oxidations delivering respectively the $\pi$-anion 55 radical and $\pi$-dianion, and the $\pi$-cation radical and $\pi$ dication. ${ }^{11}$ For 1, only the first reduction matches this reversible behavior. On the contrary, the first oxidation is fully irreversible with a more intense two-fold peak current than in reduction, as also observed in RDE voltammetry $\dagger$, 60 which indicates that the initially generated cation radical $\mathbf{1}^{++}$ undergoes a fast chemical reaction with pyridine followed by a subsequent one electron uptake (ECE-type mechanism).

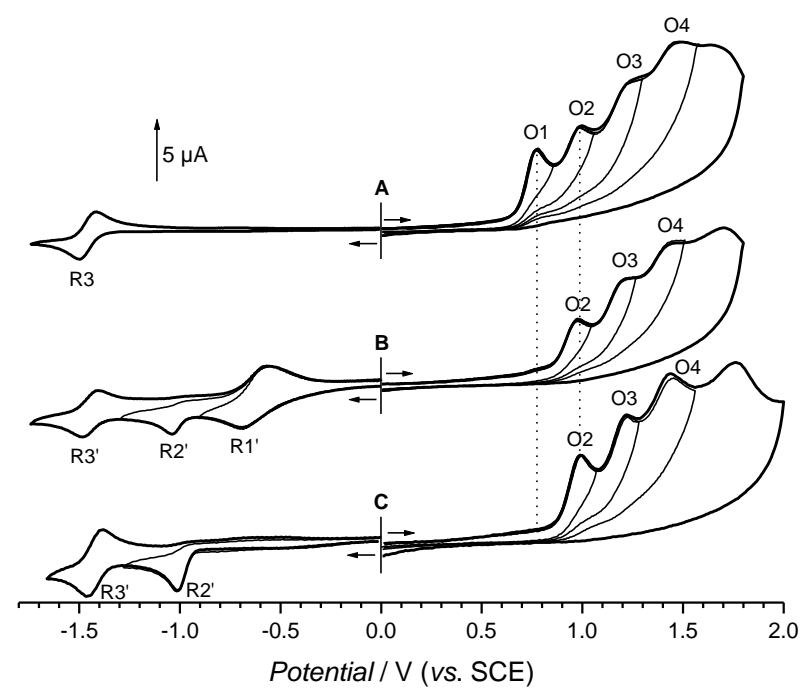

Fig. $1 \mathrm{CV}$ before (A) and after (B) electrolysis of $\mathbf{1}, \mathrm{CV}$ of $\mathbf{2}^{+}, \mathbf{P F}_{\mathbf{6}}^{-}(\mathrm{C})$ in 65 pyridine containing $0.1 \mathrm{M} \mathrm{TBAPF}_{6}\left(\mathrm{WE}: \mathrm{Pt}, \emptyset=2 \mathrm{~mm}, 0.1 \mathrm{~V} \mathrm{~s}^{-1},[1]=\right.$ $\left.5.0 \times 10^{-4} \mathrm{M},\left[\mathbf{2}^{+}, \mathbf{P F}_{6}^{-}\right]=6.3 \times 10^{-4} \mathrm{M}\right)$.

This oxidation process can then be operated at the macroscopic scale by electrolysis on a large area platinum electrode. Typically, by setting the working potential at 0.72 ${ }_{70} \mathrm{~V}$ (first step of the oxidation of $\mathbf{1}$ ), the current dropped to the residual current after an uptake of 2.0 molar equivalent of electrons, in agreement with the two electron transfer mechanism. Then, the CV of the electrolyzed solution (Fig. 1B) no longer shows the initial peak O1, which gives evidence 75 for complete conversion of $\mathbf{1}$. With the exception of the latter, the other oxidation peaks are similar as in the $\mathrm{CV}$ of $\mathbf{1}$ (potential position and current magnitude). Additionnally, the voltammogram of the electrolyzed solution (Fig. 1B) exhibits three well defined cathodic systems at $E_{p c}=-0.69 \mathrm{~V}$ (R1', 80 poorly reversible), $E_{p c}=-1.04 \mathrm{~V}\left(\mathrm{R} 2\right.$ ', irreversible) and $E_{1 / 2}=$ -1.44 V (R3', reversible). As proven by analysis of an independently prepared sample, the peak R1' is attributed to the presence of free pyridinium in solution testifying to the loss of protons during the course of electrolysis. The 
magnitude of this peak leads to a rough estimation of one $\mathrm{H}^{+}$ liberated per unit of reacted $\mathbf{1}$.

The Maldi-Tof mass spectrum of this crude solution exhibits a nearly exclusive and intense peak $\uparrow$ at $\mathrm{m} / \mathrm{z}=410$ 5 which is consistent with a magnesium porphine substituted by one pyridinium fragment and seems to indicate a nearly quantitative reaction with one very major product.

The bulk electrolysis was then scaled up $(40.0 \mathrm{mg}$, $\left.1.20 \times 10^{-4} \mathrm{~mol}, 1.49 \times 10^{-3} \mathrm{M}\right)$ in order to get enough material 10 for a complete characterization. After work-up procedure and purification on silicagel column chromatography $\dagger$, the resulting pink/red solid was recrystallized in $\mathrm{CH}_{2} \mathrm{Cl}_{2} / n$-hexane to give $55.8 \mathrm{mg}$ of pure $\mathbf{2}^{+}, \mathbf{P F}_{\mathbf{6}}{ }^{-} \cdot \mathbf{P y}$ ( $73 \%$ isolated yield).

From NMR analysis $\dagger$, the isolated compound was 15 unambiguously identified as the magnesium (II) [5- $(\mathrm{N}-$ pyridinium)porphine]hexafluorophosphate, $\quad \mathbf{2}^{+}, \mathbf{P F}_{\mathbf{6}}{ }^{-}$ coordinated by one pyridine molecule $\left(\mathbf{2}^{+}, \mathbf{P F}_{6}{ }^{-} \cdot \mathbf{P y}\right)$. In particular, the presence of only two singlets corresponding to the meso protons at $10.62 \mathrm{ppm}(1 \mathrm{H})$ and $10.61 \mathrm{ppm}(2 \mathrm{H})$ is in 20 agreement with the high symmetry of the molecule consequent on the mono-meso-substitution of the porphine macrocycle. In addition, three signals at $10.28(2 \mathrm{H}), 9.50(1 \mathrm{H})$ and $8.85 \mathrm{ppm}(2 \mathrm{H})$ exhibit correlation tasks on the ${ }^{1} \mathrm{H}-{ }^{1} \mathrm{H}$ COSY spectrum $\dagger$ and are thus attributed to the pyridinium 25 fragment. Interestingly, the $\beta$-substituted isomer was not observed at any time, even on the ${ }^{1} \mathrm{H}$ NMR spectrum of the crude solution resulting from electrolysis, II so the reaction can be considered as ideally regioselective.

Finally, considering the stoichiometry in reactants and 30 products, the overall reaction can be balanced as in Scheme 1, similar as already reported for the reaction of substituted porphyrins: ${ }^{8}$

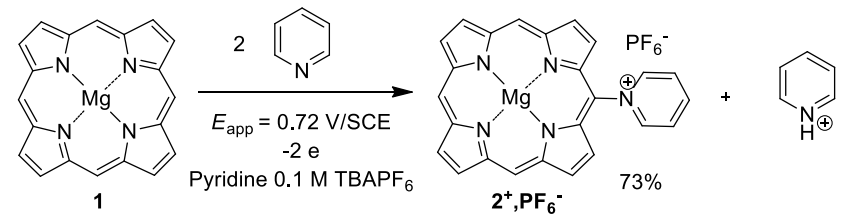

Scheme 1 Electrochemical synthesis of $\mathbf{2}^{+}, \mathbf{P F}_{6}^{-}$.

35 The CV of a pure sample of $\mathbf{2}^{+}, \mathbf{P F}_{\mathbf{6}}{ }^{-}$in pyridine (Fig. 1C) is practically identical to the one obtained after electrolysis (Fig. 1B) but without the peak R1' assigned to free pyridinium (see above), in accordance with the elimination of this compound along purification. By analogy with the previously reported ${ }_{40} \mathrm{ZnTPP}$ and $\mathrm{ZnOEP}^{8}$ pyridinium substituted derivatives the redox systems at $E_{p c}=-1.04 \mathrm{~V}$ (R2') and $E_{1 / 2}=-1.44 \mathrm{~V}$ (R3') are respectively attributed to the pyridinium moiety and the macrocycle ring as the electroactive parts of $\mathbf{2}^{+}, \mathbf{P F}_{\mathbf{6}}{ }^{-}$. Concerning the oxidatively initiated scan, it is noteworthy that 45 the entire voltammetric trace of $\mathbf{2}^{\mathbf{+}} \mathbf{\mathbf { P F } _ { \mathbf { 6 } }}{ }^{-}$is already present in the $\mathrm{CV}$ of 1 (see Fig. 1A and C) but no other peak could be attributed to an intermediate between them. This behaviour is consistent with a very fast electrochemical-chemical process occuring at the electrode surface leading instantaneously to ${ }_{50} \mathbf{2}^{+}, \mathbf{P F}_{6}{ }^{-}$as soon as $\mathbf{1}^{\cdot+}$ is generated.

In a parallel way, the reaction of Scheme 1 was attempted chemically instead of electrochemically, in pure pyridine using common oxidants such as DDQ, $\mathrm{NO}^{+}$or $\mathrm{Ag}^{+}$salts, but no reaction at all occured. This lack of reactivity could stem 55 from the deactivation of their "oxidizing power" due to their reaction with pyridine (charge transfer complexes for DDQ and $\mathrm{NO}^{+}$and coordination of pyridine for $\mathrm{Ag}^{+} \|$). These results emphasize the great interest of the electrochemical pathway for carrying out oxidation reactions in pyridine.

60 In order to check if this regioselective electrochemical meso-functionalization could be generalized, $\mathrm{PPh}_{3}$ was tested as nucleophile instead of pyridine.

The reaction was similar, provided that the conditions were modified as specified in Scheme 2:

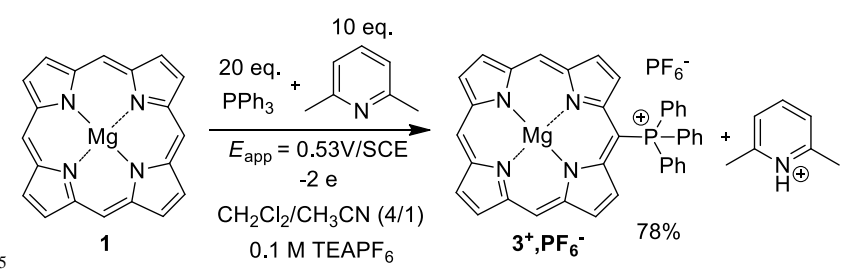

Scheme 2 Electrochemical synthesis of $\mathbf{3}^{+}, \mathbf{P F}_{6}^{-}$.

First, 2,6-lutidine is used as an encumbered base, so not competing in the nucleophilic attack of $\mathbf{1}^{++}$. Second, 20 molar equivalents of $\mathrm{PPh}_{3}$ are necessary to maximize the formation 70 of the substitution product; nevertheless this excess remains ca. 400 times lower than with pyridine, in agreement with the higher nucleophilicity of phosphine. ${ }^{10}$ Third, the electrolysis is carried out with tetraethylammonium hexafluorophosphate (TEAPF6) as a supporting electrolyte, which offers the 75 advantage of being easily separated from the electrolysis product by extraction in water.

In these conditions, starting with $40.0 \mathrm{mg}$ of $1\left(1.20 \times 10^{-4}\right.$ mol, $\left.3.0 \times 10^{-3} \mathrm{M}\right)$, the high-scale electrolysis affords after treatment ${ }^{\dagger} 69.4 \mathrm{mg}$ of $\mathbf{3}^{+}, \mathbf{P F}_{\mathbf{6}}^{-}$(isolated yield: $78 \%$ ). The 80 improvement in yield compared with Py arises from an easier purification procedure due to a facilitated removal of TEAPF6.

As for $\mathbf{2}^{+}, \mathbf{P F}_{6}{ }^{-}$, the identification of $\mathbf{3}^{+}, \mathbf{P F}_{6}{ }^{-}$is clear about the position of the substitution on the porphine ring: in the ${ }^{1} \mathrm{H}$ NMR spectrum, two singlets at $10.36(1 \mathrm{H})$ and $10.14 \mathrm{ppm}$ $85(2 \mathrm{H})$ are attributed to meso protons, so indicating unambiguously the mono-meso-substitution. Besides, on the ${ }^{31} \mathrm{P}$ NMR spectrum, two signals are observed at 24.2 (singlet) and at $-144.6 \mathrm{ppm}$ (heptuplet) for the phosphonium group and the $\mathrm{PF}_{6}{ }^{-}$anion, respectively.

90 Definite proof of the molecular structure was given from the X-ray diffraction analysis on single crystals of $\mathbf{3}^{+}, \mathbf{P F}_{\mathbf{6}}{ }^{-}$ obtained from slow diffusion of toluene in a $\mathrm{CHCl}_{3} / \mathrm{EtOH}$ solution containing the meso-substituted porphine (Fig. 2). Whereas an iron(III) $\beta$-(triphenylphosphonium)porphyrine $\mathrm{X}$ ${ }_{95}$ ray structure has already been described, ${ }^{12}$ to our best knowledge $\mathbf{3}^{+}, \mathbf{P F}_{6}{ }^{-}$is the first meso-phosphonium porphyrin crystallographic structure ever published and joins the very restricted family of magnesium porphyrin crystallographic structures $\$$. Interestingly, two $\mathbf{3}^{+}, \mathbf{P F}_{\mathbf{6}}^{-}$molecules form a $\pi$ 100 stacked dimer with a slipped cofacial orientation as a model of the photosynthetic special pair ${ }^{13}$ (distance between the two mean plane formed by the $\mathrm{C}$ and $\mathrm{N}$ atoms of each porphyrin core $=3.228 \AA$ ). The metal cation is pentacoordinated by four 
nitrogen atoms $(2.073(4) \leq \mathrm{Mg}-\mathrm{N} \leq 2.095(4) \AA)$ and one axial EtOH $(\mathrm{Mg}-\mathrm{O}=2.044(3) \AA)$. As expected for a pentacoordinated complex, ${ }^{14}$ the $\mathrm{Mg}$ cation lies outside the mean plane described by the four $\mathrm{N}$ atoms $(\mathrm{Mg}-$ mean plane $=$ $50.355 \AA$ ). Otherwise, the meso $\mathrm{C}-\mathrm{P}^{+}$bond $(\mathrm{C}-\mathrm{P}=1.794(4) \AA)$ lies slightly misaligned to the 24 atom mean plane $(\mathrm{P}-$ mean plane $=0.390(2) \AA)$.

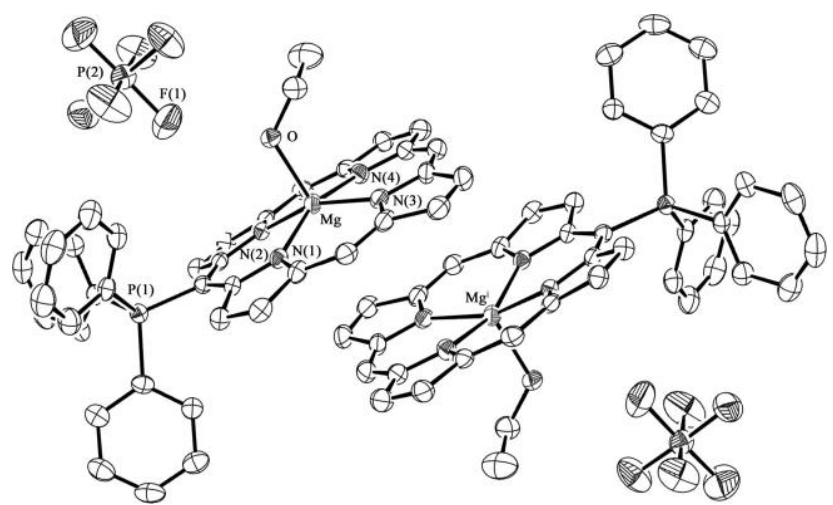

Fig. 2 Ortep view of the $\pi$-stacked dimer of $\mathbf{3}^{+}, \mathbf{P F}_{6}^{-}$. Thermal ellipsoids 10 are scaled to the $50 \%$ probability level. Toluene molecules and hydrogen atoms are omitted for clarity. Symmetry operation used to generate equivalent atoms: i: 1-x, -y, 2-z.

In conclusion, the electrochemical functionalization of porphine, and more particularly $\mathrm{Mg}$ (II) porphine $\mathbf{1}$, has been 15 achieved for the first time. Oxidation of $\mathbf{1}$ in presence of pyridine and phosphine leads to the meso-substituted pyridinium and phosphonium porphyrins with a competitive yield and total regioselectivity. The present studies are directed towards polysubstitution and functionalization by 20 other nucleophiles. Undoubtely, the method offers many synthetic possibilities and, if extended, could be of great utility in porphyrin chemistry.

The authors would like to thank the Centre National de la Recherche Scientifique, the Conseil Régional de Bourgogne 25 and the Université de Bourgogne for their financial support. The authors are grateful to Pr. Yves Mugnier for his helpful discussions and to Sophie Dalmolin for technical support.

\section{Notes and references}

${ }^{a}$ Institut de Chimie Moléculaire de l'Université de Bourgogne, UMR ${ }_{30}$ CNRS 5260, Université de Bourgogne, BP 47870, 21078 DIJON Cedex, France.E-mail: charles.devillers@u-bourgogne.fr; dominique.lucas@ubourgogne.fr

$\dagger$ Electronic Supplementary Information (ESI) available: Experimental details and characterization data. See DOI: 10.1039/b000000x/

35 If In the crude solution, $\mathbf{2}^{+}, \mathbf{P F}_{\mathbf{6}}^{-1} \mathbf{H}$ NMR yield is higher than $90 \%$.

$\S$ When adding one drop of Py on a few mg of yellow DDQ, the mixture turned instantaneously black in agreement with the formation of a charge transfer complex.

$\|$ In our conditions (pyridine $0.1 \mathrm{M} \mathrm{TBAPF}_{6}$ ), $\mathrm{Ag}^{+}$is reduced at $c a-0.25$

40 V/SCE (WE: Pt) against $0.65 \mathrm{~V}$ in $\mathrm{CH}_{2} \mathrm{Cl}_{2} 0.1 \mathrm{M} \mathrm{TBAPF}_{6}$.

$\ddagger$ To date, according to $\mathrm{CCDC}$, only 25 magnesium porphyrins crystallographic structures exist.

Spectroscopic data for $\mathbf{2}^{+}, \mathbf{P F}_{\mathbf{6}} \cdot \mathbf{P y}: R_{f}=0.63\left(\mathrm{SiO}_{2}, \mathrm{CH}_{2} \mathrm{Cl}_{2} / \mathrm{MeOH}, 80 / 20\right.$, v/v); MALDI-TOF MS (dithranol): $[\mathrm{M}]^{+}=410 ;{ }^{1} \mathrm{H}$ NMR $\left(\mathrm{CD}_{3} \mathrm{COCD}_{3}\right.$, $\left.{ }_{45} 600 \mathrm{MHz}, 298 \mathrm{~K}\right): \delta$ (ppm) 7.15 (m, $m$-Py, 2H), 7.63 (m, $p$-Py, 1H), 7.73 (br, $o$-Py, 2H), $8.85\left(\mathrm{~m}, m-\mathrm{Py}^{+}, 2 \mathrm{H}\right), 8.92\left(\mathrm{~d},{ }^{3} J=4.2 \mathrm{~Hz}, \beta\right.$-Pyrr, $\left.2 \mathrm{H}\right)$, $9.50\left(\mathrm{~m}, p-\mathrm{Py}^{+}, 1 \mathrm{H}\right), 9.66\left(\mathrm{~d},{ }^{3} \mathrm{~J}=4.2 \mathrm{~Hz}, \beta\right.$-Pyrr, $\left.2 \mathrm{H}\right), 9.68\left(\mathrm{~d},{ }^{3} J=4.8\right.$ $\mathrm{Hz}, \beta$-Pyrr, 4H), $10.28\left(\mathrm{~d},{ }^{3} J=4.8 \mathrm{~Hz}, o-\mathrm{Py}^{+}, 2 \mathrm{H}\right), 10.61$ (s, meso, 2H),
10.62 (s, meso, 1H). $\lambda_{\max }$ (pyridine)/nm (log $\left.\varepsilon\right) 321$ (4.41), 419 (5.50), 555 50 (4.22), 588 (3.69), 597 (3.63); Elemental analysis (Found: C, 54.83; H, 3.39; N, 12.72\%. Calc. for $\mathrm{C}_{30} \mathrm{H}_{21} \mathrm{~F}_{6} \mathrm{MgN}_{6} \mathrm{P} \cdot \mathrm{H}_{2} \mathrm{O}: \mathrm{C}, 55.20 ; \mathrm{H}, 3.55 ; \mathrm{N}$, $12.87 \%) .3^{+}, \mathbf{P F}_{6}^{-}: R_{f}=0.51\left(\mathrm{Al}_{2} \mathrm{O}_{3}, \mathrm{CH}_{2} \mathrm{Cl}_{2} / \mathrm{MeOH}, 95 / 5\right.$, v/v); MALDITOF MS (dithranol): $[\mathrm{M}]^{+}=593 ;{ }^{1} \mathrm{H}$ NMR $\left(\mathrm{CD}_{3} \mathrm{OD}, 600 \mathrm{MHz}, 298 \mathrm{~K}\right): \delta$ (ppm) 7.70 (m, $m$-Ph, 6H), 7.89 (m, $p$-Ph, 3H), 8.01 (m, o-Ph, 6H), 8.34 ${ }_{55}\left(\mathrm{~d},{ }^{3} J=4.5 \mathrm{~Hz}, \beta\right.$-Pyrr, $\left.2 \mathrm{H}\right), 8.98\left(\mathrm{~d},{ }^{3} J=4.5 \mathrm{~Hz}, \beta\right.$-Pyrr, $\left.2 \mathrm{H}\right), 9.31\left(\mathrm{~d},{ }^{3} J=\right.$ $4.1 \mathrm{~Hz}, \beta$-Pyrr, $2 \mathrm{H}), 9.42\left(\mathrm{~d},{ }^{3} J=4.1 \mathrm{~Hz}, \beta\right.$-Pyrr, $\left.2 \mathrm{H}\right), 10.14$ (s, meso, $2 \mathrm{H}), 10.36$ (s, meso, $1 \mathrm{H}) ;{ }^{31} \mathrm{P}\left(\mathrm{CD}_{3} \mathrm{OD}, 243 \mathrm{MHz}, 298 \mathrm{~K}\right): \delta(\mathrm{ppm})-144.6$ $\left(\mathrm{m}, \mathrm{PF}_{6}{ }^{-}\right), 24.2\left(\mathrm{~s}, \mathrm{P}^{+}\right) . \lambda_{\max }\left(\mathrm{CH}_{2} \mathrm{Cl}_{2}\right) / \mathrm{nm}(\log \varepsilon) 329$ (4.27), 415 (5 .43), 555 (4.01), 595 (4.30); Elemental analysis (Found: C, 60.63; H, 3.74; N, $607.15 \%$. Calc. for $\left.\mathrm{C}_{38} \mathrm{H}_{26} \mathrm{~F}_{6} \mathrm{MgN}_{4} \mathrm{P}_{2} \cdot \mathrm{H}_{2} \mathrm{O}: \mathrm{C}, 60.30 ; \mathrm{H}, 3.73 ; \mathrm{N}, 7.40 \%\right)$.

Crystal data for $\mathbf{3}^{+}, \mathbf{P F}_{6}^{-}: \mathrm{C}_{40} \mathrm{H}_{32} \mathrm{MgN}_{4} \mathrm{OP}, 0.5 \mathrm{C}_{7} \mathrm{H}_{8}, \mathrm{PF}_{6}, \mathrm{M}=831.01$, crystal size $0.13 \times 0.10 \times 0.08 \mathrm{~mm}$, monoclinic, space group $\mathrm{P} 2{ }_{1} / \mathrm{c}, \mathrm{a}=$ 9.4786(4) $\AA$, $b=25.8868(11) \AA, c=16.9780(7) \AA, \beta=112.241(2)^{\circ}, \mathrm{V}=$ $3856.0(3) \AA^{3}, Z=4, D c=1.431$ g.cm $\mathrm{cm}^{-1}, \mu=0.20 \mathrm{~mm}^{-1}, 16677$ reflections 65 were collected at $115 \mathrm{~K}$ on a Nonius Kappa CCD diffractometer $(\lambda=$ $0.71073, \sin \theta / \lambda=0.65$, index range $: \mathrm{h}=-12,12 ; \mathrm{k}=-33,33 ; 1=-22,22)$. 8798 independent $\left(R_{\text {int }}=0.065\right)$ and 5987 observed reflections $(I>2 \sigma(I))$, 540 refined parameters, 42 restraints, $\mathrm{R}$ for observed reflections: $\mathrm{R}_{1}=$ $0.0904, \mathrm{wR}_{2}=0.1549, \mathrm{R}$ for all data: $\mathrm{R}_{1}=0.1367, \mathrm{wR} 2=0.1767$, 70 Goodness of fit $=1.133$, maximum residual electron density 0.687 and 0.495 . The structures were solved using direct methods (SIR92) ${ }^{15}$ and refined with full-matrix least-square methods based on $\mathrm{F}^{2}$ (Shelx-97) ${ }^{16}$ with the aid of the Wingx program ${ }^{17}$. CCDC deposition number : 796284

1. E. Song, C. Shi and F. C. Anson, Langmuir, 1998, 14, 4315; C. 75 Bucher, C. H. Devillers, J.-C. Moutet, G. Royal and E. Saint-Aman, Chem. Commun., 2003, 888; H. Imahori, M. Kimura, K. Hosomizu, T. Sato, T. K. Ahn, S. K. Kim, D. Kim, Y. Nishimura, I. Yamazaki, Y. Araki, O. Ito and S. Fukuzumi, Chem. Eur. J., 2004, 10, 5111; L. Wei, K. Padmaja, W. J. Youngblood, A. B. Lysenko, J. S. Lindsey and D. F. Bocian, J. Org. Chem., 2004, 69, 1461.

2. J. E. Drach and F. R. Longo, J. Org. Chem., 1974, 39, 3282; R. Schlözer and J.-H. Fuhrhop, Angew. Chem. Int. Ed., 1975, 14, 363; D.-F. Shi and R. T. Wheelhouse, Tetrahedron Lett., 2002, 43, 9341; S. Hatscher and M. O. Senge, Tetrahedron Lett., 2003, 44, 157; M.

85 O. Senge, Acc. Chem. Res., 2005, 38, 733; C. Ryppa, M. O. Senge, S. S. Hatscher, E. Kleinpeter, P. Wacker, U. Schilde and A. Wiehe, Chem. Eur. J., 2005, 11, 3427.

3. D. K. Dogutan, M. Ptaszek and J. S. Lindsey, J. Org. Chem., 2007, 72, 5008 .

90 4. F. J. Kampas, K. Yamashita and J. Fajer, Nature, 1980, 284, 40; K. Yamashita, Chem. Lett., 1982, 1985.

5. C. H. Devillers, D. Lucas, A. K. D. Dime, Y. Rousselin and Y. Mugnier, Dalton Trans., 2010, 39, 2404.

6. M. A. Vorotyntsev, D. V. Konev, C. H. Devillers, I. Bezverkhyy and 95 O. Heintz, Electrochim. Acta, 2010, 55, 6703.

7. K. M. Smith, G. H. Barnett, B. Evans and Z. Martynenko, J. Am. Chem. Soc., 1979, 101, 5953.

8. A. Giraudeau, L. Ruhlmann, L. E. Kahef and M. Gross, J. Am. Chem. Soc., 1996, 118, 2969.

100 9. H. J. Shine, A. G. Padilla and S.-M. Wu, J. Org. Chem., 1979, 44, 4069; L. E. Kahef, M. E. Meray, M. Gross and A. Giraudeau, Chem. Commun., 1986, 621; L. E. Kahef, M. Gross and A. Giraudeau, Chem. Commun., 1989, 963.

10. L. Ruhlmann and A. Giraudeau, Chem. Commun., 1996, 2007.

105 11. K. M. Kadish, E. V. Caemelbecke and G. Royal, in The Porphyrin Handbook, eds. K. M. Kadish, K. M. Smith and R. Guilard, Academic Press, 2000, Vol. 8, Chap. 55, pp. 1-114.

12. A. Małek, L. Latos-Grażyński, T. J. Bartczak and A. Żądło, Inorg. Chem., 1991, 30, 3222.

110 13. J. Deisenhofer and H. Michel, Science, 1989, 245, 1463.

14. M. P. Byrn, C. J. Curtis, Y. Hsiou, S. I. Khan, P. A. Sawin, S. K. Tendick, A. Terzis and C. E. Strouse, J. Am. Chem. Soc., 1993, 115, 9480 .

15. A. Altomare, G. Cascarano, C. Giacovazzo and A. Guagliardi, $J$. 115 App. Cryst., 1993, 26, 343.

16. G. M. Sheldrick, SHELX97 (Includes SHELXS97 and SHELX97), Release 97-2, Programs for Crystal Structure Analysis, University of Göttingen, 1998.

17. L. J. Farrugia, J. Appl. Cryst, 1999, 32, 837. 